\title{
Immunohistochemical Characterization of Pituitary Stellate Cells in Rats
}

\author{
Fujio YOSHIMURA AND HARUo NOGAMI \\ Department of Anatomy, Jikei University School of Medicine, \\ Minatoku Tokyo 105, Japan
}

\begin{abstract}
Synopsis
Pituitary stellate cells from the normal adult male rats were immunohistochemically investigated at the light microscopical level by the use of rat TSH- $\beta$, porcine ACTH ${ }^{1-39}$, porcine $\mathrm{ACTH}^{17-39}$, rat FSH and ovine FSH antisera. They were characterized by the stellate shape and a mimic engulfment of acidophils. In the present study, they were identified to be the ACTH cells but some were TSH cells. Although most of the corticotrophs showed a peripheral fringe immunostained with the porcine ACTH ${ }^{17-39}$ antiserum, some others were stained diffusively throughout the cytoplasm. The latter cells coincided, in shape and in homogenous stainability of the cytoplasm, with the stellate TSH cells. Both cells did not correspond but were independent in distribution at the same site of the gland on the adjacent two sections. The stellate type of FSH cells could react with the ovine FSH antiserum, but not with the rat FSH antiserum. Absorption tests of the ovine $\mathrm{FSH}$, procine $\mathrm{ACTH}^{1-39}$ and procine $\mathrm{ACTH}^{17-39}$ antisera were carried out by an application of procine ACTH. In consequence, the porcine $\mathrm{ACTH}^{1-39}$ and porcine $\mathrm{ACTH}^{17-39}$ antisera were absorbed efficaciously by the ACTH antigen at the dose of $10 \mu \mathrm{g} / \mathrm{ml}$, but the ovine FSH antiserum was not enough absorbed by ACTH in the doses of less than $1 \mathrm{mg} / \mathrm{m} l$. It was not finally concluded whether or not the single stellate cells produced ACTH and FSH.
\end{abstract}

Pituitary stellate cells represents star-like outline due to the cytoplasmic processes extended among the neighbouring cells.

Their feature impresses an embracement of the adjacent cells as observed upon tissue sections. The stellate cells in the rat pituitary have been regarded, by their immunohistochemical property, as Siperstein's (1970) corticotrophs with a peripheral row arrangement of secretory granules in the cytoplasm. On the other hand, the stellate cells have not generally been believed to contain TSH. However, Moriarty and Tobin (1976) found the presence of stellate thyrotrophs and emphasized that the secretory granules in the stellate thyrotrophs were constantly smaller in diameter than those in the corticotrophs. Recently, Moriarty and Garner (1977) found, in rat pituitaries, some gonadotrophs containing two different secretory granules stained either with porcine $\mathrm{ACTH}^{17-39}$ antiserum or with FSH- $\beta$ antiserum in their cytoplasm. The third type of gonadotroph revealed by Moriarty and Garner coincides morphologically with Siperstein's corticotroph. The purpose of this study is to research for the immunohistochemical characterization of the stellate cells at the light microscopical level in the normal male rat pituitaries.

Received May 7, 1979. 


\section{Materials and Methods}

Pituitary glands were carefully removed from the Wistar-Imamichi male rats, 60 days of age, under the nembutal anesthesia. They were fixed in formol sublimate, and embedded in paraplast. Thin sections $2 \mu$ in thickness were made with glass knives.

\section{Immunohistochemical staining procedure}

The unlabeled antibody method by Sternberger et al. (1970) was used: After rehydration, the sections were incubated with normal rat serum diluted 1:20 with phosphate buffered saline, (PBS, 0.9\% $\mathrm{NaCl} / 0.02 M$ phosphate buffer, $\mathrm{pH}$ 7.4). After washing with PBS, they were incubated again with the first rabbit antisera at $30^{\circ} \mathrm{C}$ for $2 \mathrm{hrs}$. The first antisera consisted of 1) rat TSH- $\beta$ and rat FSH (whole) antisera (Gift from Dr. A. F. Parlow, NIH, U.S.A.), 2) ovine FSH (whole) antiserum (Gift from Dr. M. Shiino, San Antonio, U.S.A.; antigen is NIH ovine FSH), 3) porcine $\mathrm{ACTH}^{1-39}$ and porcine ACTH $^{17-39}$ antisera (Gift from Dr. S. Daikoku, Tokushima, Japan; antigen is pornice corticotropin). Prior to the use, they were diluted, as described below, with PBS to prevent the non-specific over staining of the background. Subsequently, they were incubated with rat anti-rabbit IgG and then with PAP (peroxidase anti peroxidase complex, given from Dr. Daikoku), both of which were diluted $1: 50$ with PBS.

After accomplishment of the above treatments, the sections were incubated in 3, $3^{\prime}$-diaminobenzidine tetrahydrochloride (DAB) solution to visualize the localization of the antigens for $30 \mathrm{~min}$ at room temperature. Four mg of DAB was dissolved in $100 \mathrm{ml}$

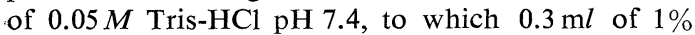
$\mathrm{H}_{2} \mathrm{O}_{2}$ were added. In order to examine the specificity of the immunohistochemical staining, we tried to substitute the normal rat serum for the first antisera in the attempt of the control experiment. The two adjacent sections were examined immunohistochemically if the same cells could react with two different kinds of antisera.

\section{Absorption test of the ovine FSH (whole) anti- serum}

Absorption test of the ovine FSH antiserum by the procine ACTH (Sigma grade II) was carried out. Also pACTH ${ }^{1-39}$ and pACTH $^{17-39}$ antisera were absorbed by the porcine ACTH. Various doses of porcine ACTH from $1 \mu \mathrm{g}$ to $1 \mathrm{mg} / \mathrm{m} l$ mixed with the same volume of the antisera (ovine FSH, pACTH ${ }^{1-39}$ and $\mathrm{pACTH}{ }^{17-39}$ ) were incubated for 2 weeks at $4^{\circ} \mathrm{C}$. The pituitaries were immunostained with the absorbed ovine FSH, pACTH ${ }^{17-39}$ and $\mathrm{pACTH}^{1-39}$ antisera. Unabsorbed antisera incubated with the same volume of PBS were used for the control of absorp- tion test. Five serial sections $2 \mu$ in thickness were prepared to examine the absorption effectiveness of the antisera against FSH, pACTH ${ }^{1-39}$ and $\mathrm{dACTH}^{17-39}$ by the porcine ACTH at the sequential doses of $0 \mu \mathrm{g}$ (control), $1 \mu \mathrm{g}, 10 \mu \mathrm{g}, 100 \mu \mathrm{g}$ and $1 \mathrm{mg} / \mathrm{ml}$. Staining properties of the absorbed three antisera with porcine ACTH of $1 \mathrm{ug}, 10 \mathrm{ug}, 100 \mathrm{ug}$ and $1 \mathrm{mg} / \mathrm{ml}$ were compared, through the immunoreactivities to the same stellate cells on the adjacent sections, with those of the control unabsorbed antisera.

\section{Observation}

Comparison of two kinds of stellate cells stained each with the porcine ACTH $H^{17-39}$ and rat TSH- $\beta$ antisera:

Immunostained corticotrophs are scattered throughout the gland, while immunostained TSH-cells are predominantly distributed at the center of the gland. When the distribution aspects of corticotrophs and thyrotrophs are compared in detail on the adjacent two sections (Figs. 1 and 2), it can be learnend that the two kinds of cells are never conformable, but indepenpently localized at the same site of the gland. The corticotrophs are usually of stellate shape with the cytoplasmic processes, being characterized by an embracement of the acidophils. They form a cluster at the various areas of the gland (arrow in Fig. 5), or sometimes solitarily distributed. Their peripheral cytoplasm is strongly stained with the pACTH 17-39 antiserum, while their central one is not stained, so that the cells constitute the immunoreactive peripheral fringe (Figs. 5 and 6). This may correspond to Siperstein's corticotrophs with a row arrangement of secretory granules along the cytoplasmic membrane. The presence of particular stellate corticotrophs such as stained intensively or diffusively without fringe is noteworthy (arrow in Fig. 6).

The thyrotrophs stained with the TSH- $\beta$ antiserum are large and polygonal, oval or polyhedral (Fig. 3), and sometimes irregularly elongated, representing the stellate shape (Fig. 4), whose narrow cytoplasm is 

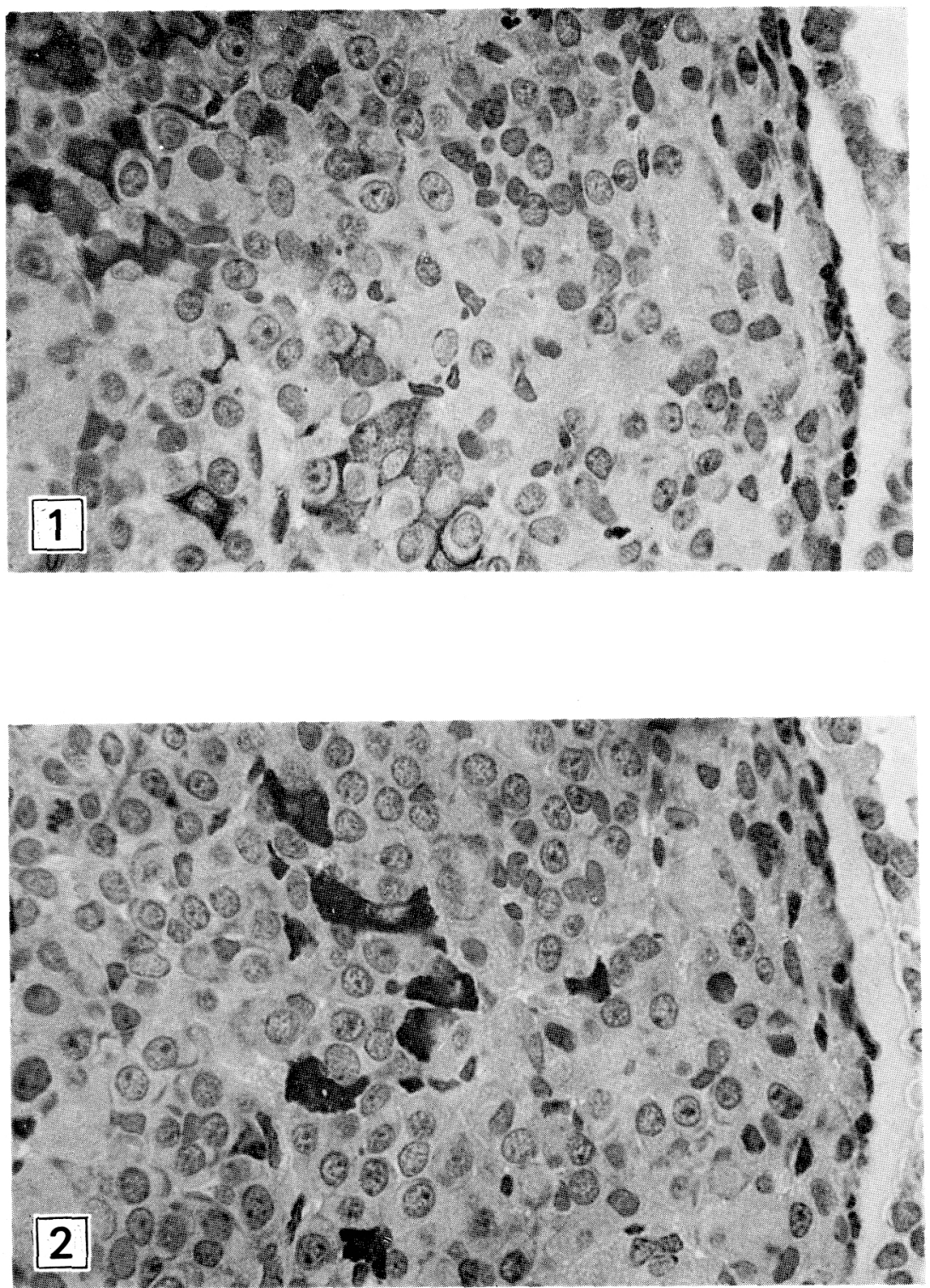

Figs. 1 and 2. Comparison of the distributions of immunoreactive cells at the same site of the normal rat pituitary on the adjacent two sections. 1, stained with a $1: 100$ dilution of the pACTH ${ }^{17-39}$ antiserum ; 2, stained with a $1: 8000$ dilution of the rat TSH- $\beta$ antiserum. Both ACTH and TSH cells never correspond, but independent. 

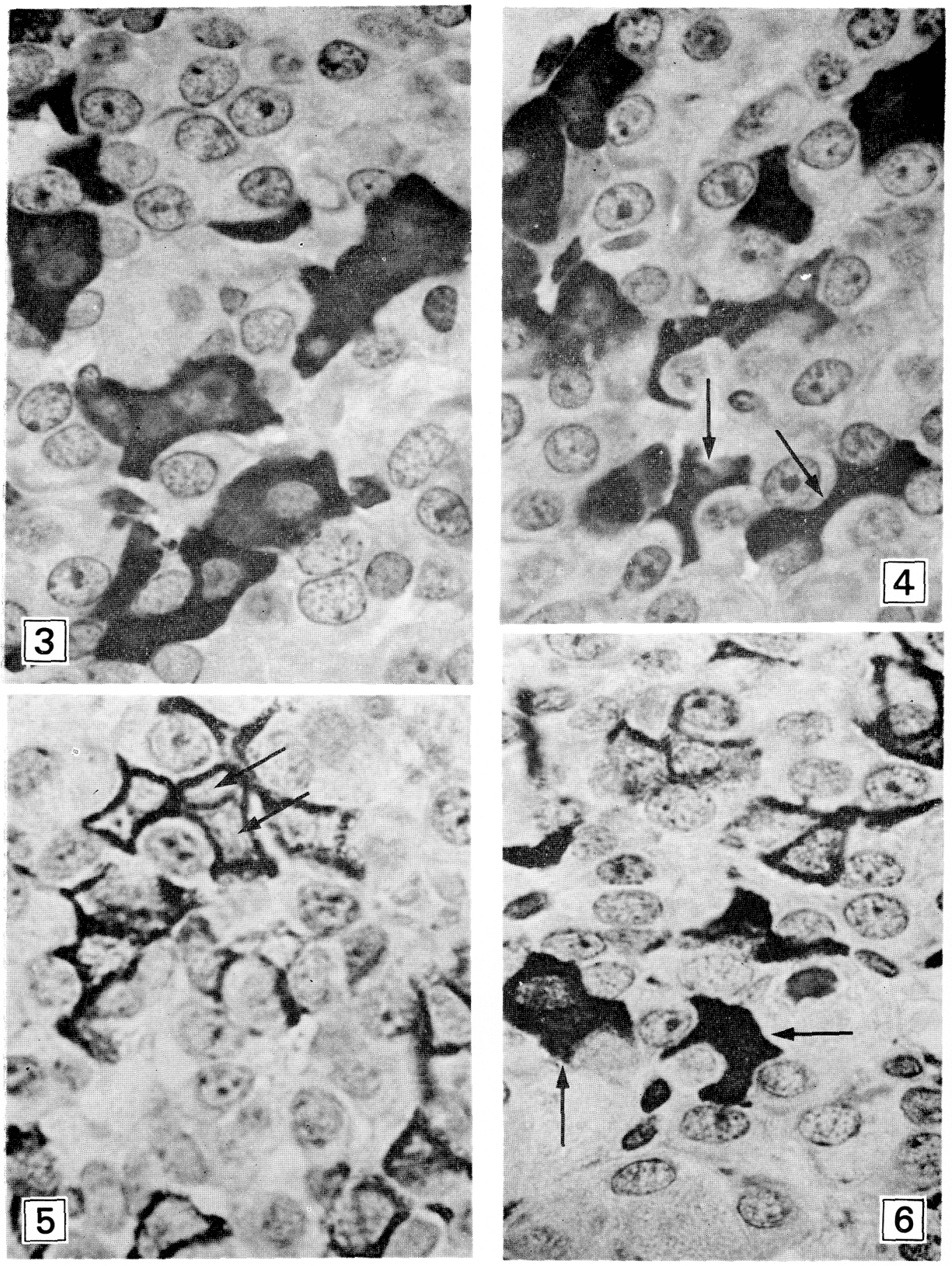

Figs. 3 and 4. Polygonal and stellate thyrotrophs in the rat pituitary, immunostained with a $1: 8000$ dilution of the rat TSH- $\beta$ antiserum. The latter shows stellate shape $(\downarrow)$ and an embracement of the neighbouring acidophils.

Figs. 5 and 6 . Stellate corticotrophs in the rat pituitary, immunostained with a $1: 100$ dilution of the pACTH ${ }^{17-39}$ antiserum. Two different stellate corticotrophs are distinguished by their staining properties. One is surrounded by reactive fringe ( $\downarrow$ in Fig. 5), and the other is homogeneously stained ( $\downarrow$ in Fig. 6). 

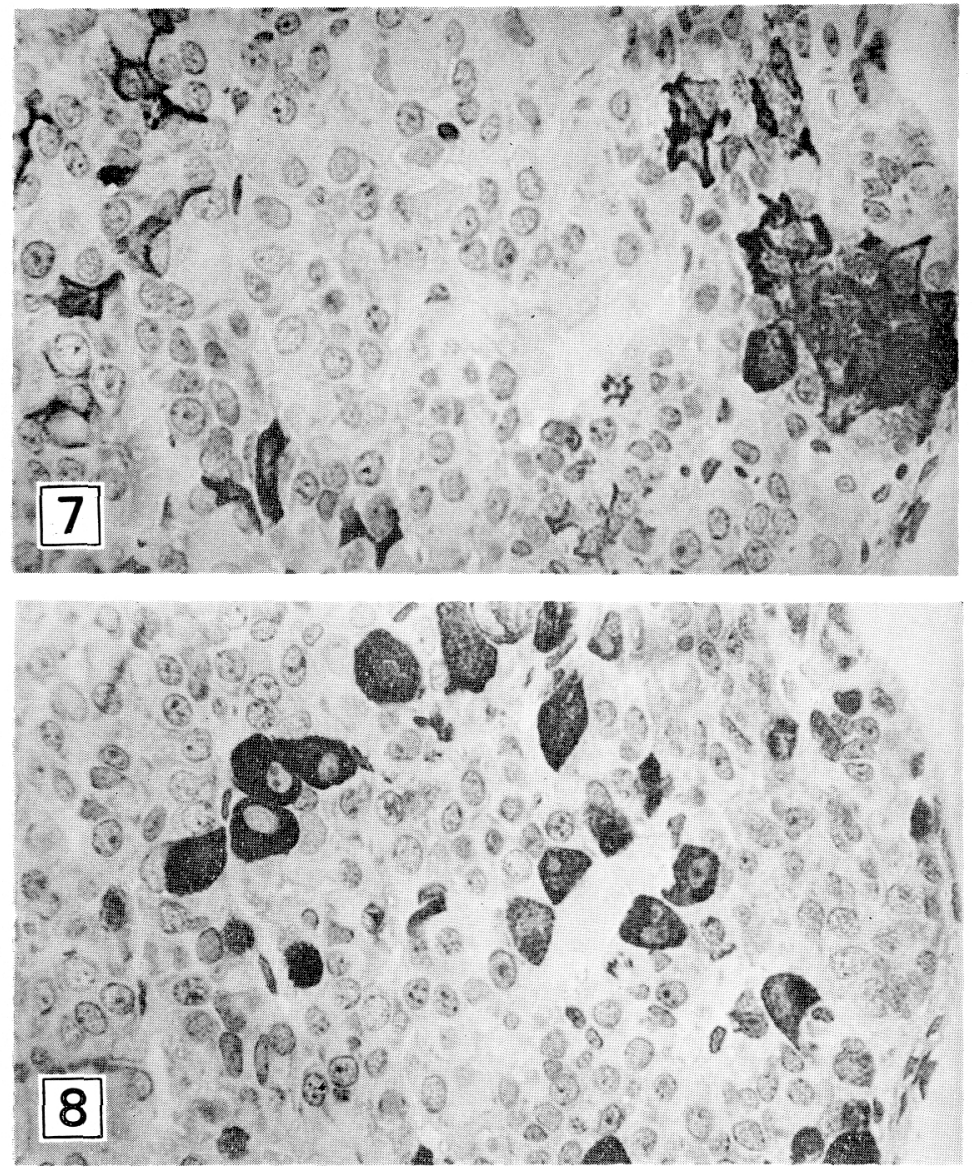

Figs. 7 and 8. Comparison of the distribution of immunoreactive cells at the same site of the gland on the adjacent two sections. 7, stained with a $1: 100$ dilution of the pACTH ${ }^{17-39}$ antiserum; 8 , stained with a $1: 300$ dilution of the rat FSH (whole) antiserum. Both ACTH and FSH cells are not comformable. crooked and occasionally embraces several acidophils (arrow in Fig. 4) The cytoplasm of both types of thyrotrophs is intensively and diffusively stained. It can be understood through the comparison of Fig. 6 (arrows) with Fig. 4 (arrows) that the stellate thyrotrophs are similar in shape to the particular corticotrophs whose whole cytoplasm is intensively staineo with ACTH antisera.

Comparison of staining abilities of the stellate cells by the porcine ACTH $H^{17-39}$, rat FSH and ovine FSH (whole) antisera

Most gonadotrophs immunostained with the rat FSH antiserum represent spherical, ovoid or polyhedral shape, but stellate cells show no immunoreaction with this antiserum throughout the gland. Examined on the adjacent two sections stained with the pACTH ${ }^{17-39}$ and rat FSH antisera, two immunoreactivities were not found on the same cells with reference to their shape and localization, so that both kinds of cells were immunohistochemically quite independent or completely separate (Figs. 7 and 8). In high magnification, most FSH gonadotrophs belong to the classical FSH cells containing the encircled distribution of Golgi apparatus (white arrow in Fig. 9), but other immunostained stellate FSH cells were seldom perceptible in the gland (black arrow in Fig. 9).

The stellate cells stained with the ovine FSH antiserum were found scattering. The distribution aspect of corticotrophs utterly corresponds with that of stellate cells stained 


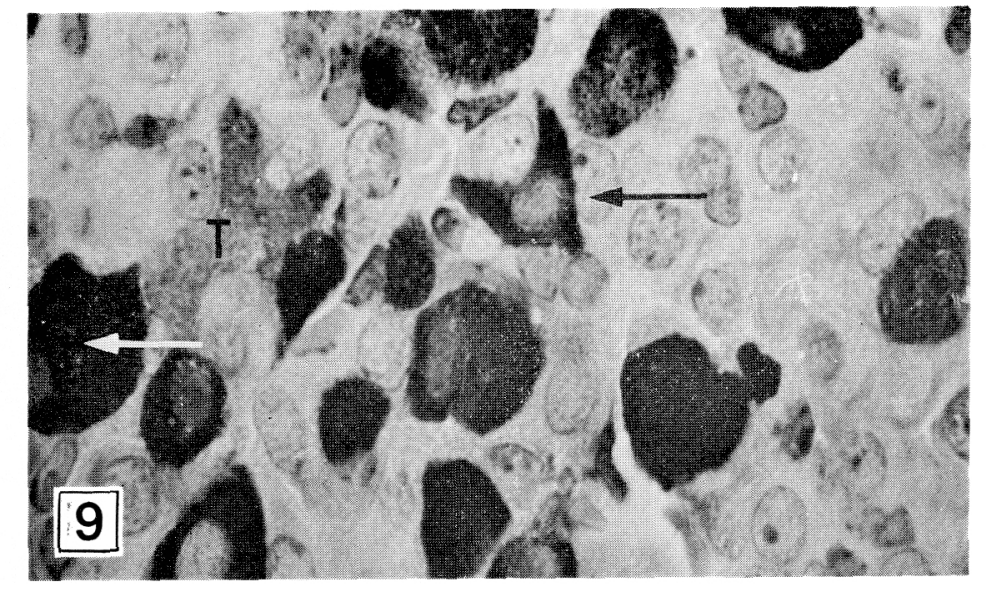

with ovine FSH antiserum. Through the exact comparision on the adjacent sections (Figs. 10 and 11), it can be known that both the types of stellate cells are comformable. The large spherical FSH-gonadotrophs are immunohistochemically negative with the ACTH antiserum at the corresponding sites of the gland.

\section{Absorption test:}

Three antisera against ovine FSH (whole), $\mathrm{pACTH}^{1-39}$ and $\mathrm{pACTH}^{17-39}$ were absorbed by various doses of porcine ACTH. The results are shown in Table 1. Immunoreactivities of those antisera to the same stellate cells were compared on the adjacent sections. It was learned that immunoreactivities with the ovine FSH antisera to the stellate cells began to be reduced after the addition of a large amount of porcine ACTH (1 mg), but immunostaining ability was never completely lost by any doses. On the other hand, immunoreactivities with the antisera against pACTH ${ }^{1-39}$ to the same stellate cells were efficaciously lost even after the addition of a small amount of porcine ACTH of $1 \mu \mathrm{g} / \mathrm{m} l$; those with the antisera against pACTH ${ }^{17-39}$ were completely lost after the addition of porcine ACTH of $10 \mu \mathrm{g} / \mathrm{ml}$ or more.
Fig. 9. FSH gonadotrophs stained with a $1: 300$ dilution of the rat $\mathrm{FSH}$ antiserum. They are commonly spherical or oval, but infrequently polygonal in shape (black arrow). The former is characterized by the existence of encircled distribution of Golgi cisternae (white arrow); a ghost TSH cell (T) is detectable probably due to cross-reactivity.
The presence of stellate thyrotrophs except for the ordinary polygonal and polyhedral ones was confirmed immunohistochemically in rats in this study. The stellate shape and an embracement of the neighbouring acidophils are their two major morphological criteria. It was observed on the adjacent sections that the stellate thyrotrophs did not correspond with the corticotrophs. Most corticotrophs in rat pituitary are chracterized by the peripheral row arrangement of secretory granules, and this feature is indispensable for identifying them electron microscopically (Baker et al., 1970; Baker and Drummond, 1972; Moriarty and Halmi, 1972). It was confirmed at the light microscopical level by us that the stellate corticotrophs showed the immunoreactive fringe at the periphery of cytoplasm. We also found some other corticotrophs diffusively or intensively immunostained with pACTH ${ }^{17-39}$ antiserum, probably due to the existence of numerous secretory granules throughout the cytoplasm. They resemble, both in shape and in staining density, the stellate thyrotrophs ( $\downarrow$ in Figs 4 and 6). However, Moriarty and Tobin (1970) clearly distinguished, at the electron microscopic level, two stellate cells, namely thytotrophs and corticotrophs, 

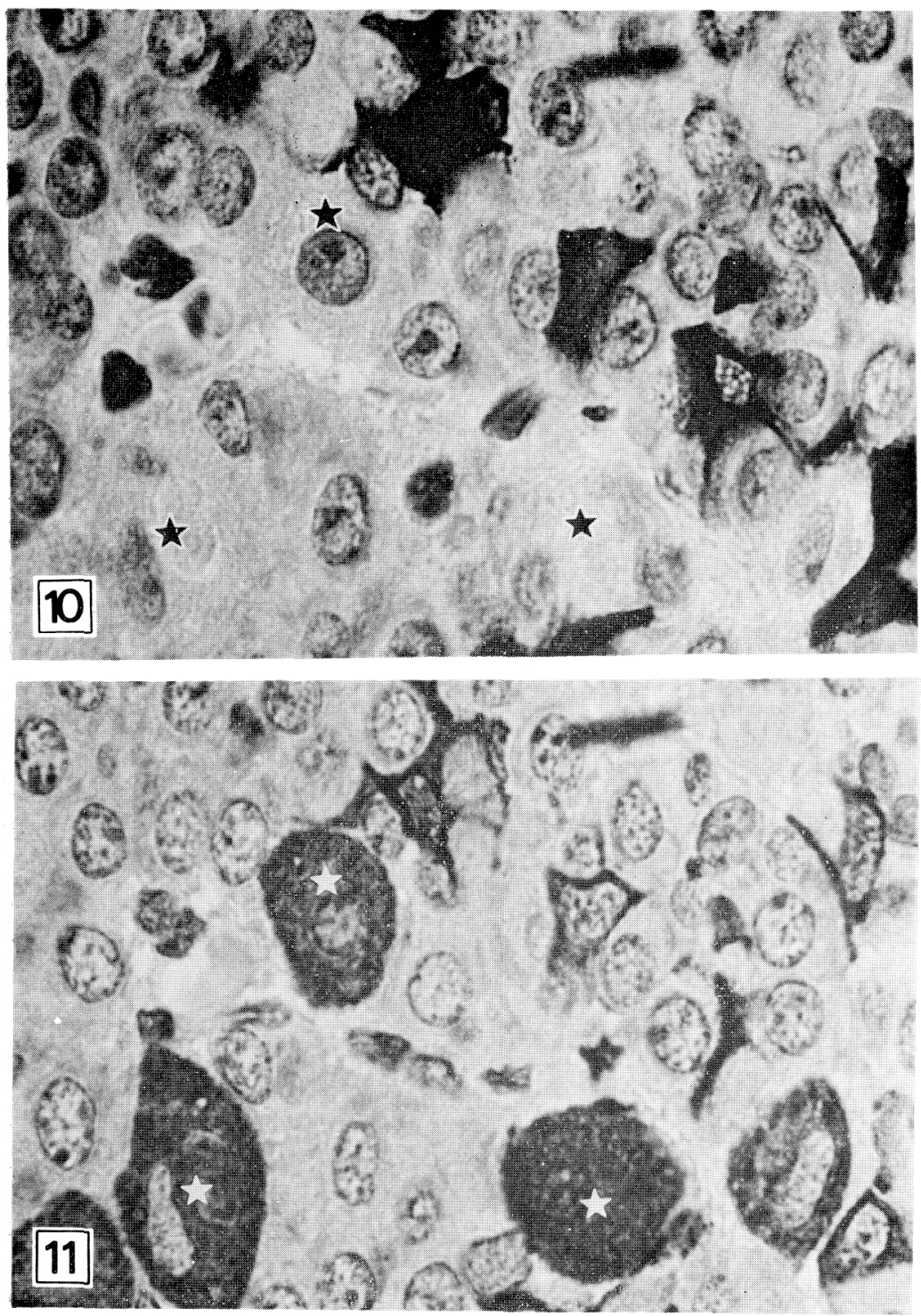

Figs. 10 and 11 . Comparison of the distributions of immunoreactive cells at the same site of the gland on the adjacent two sections. 10, stained with a $1: 100$ dilution of the pACTH ${ }^{17-39}$ antiserum; 11 , stained with a $1: 2500$ dilution of the ovine FSH (whole) antiserum. The large spherical or oval FSH cell (it $\star$ ) do not correspond, but the stellate cells are comformable. in rats, according to the different size of secretory grauules. Nagata et al. (1980) pointed out, in their foregoing paper, the presence of the two particular stellate cells filled either with the dense secretory granules $150-250 \mathrm{~nm}$ in diameter or with the minute secretory granules of low density about 50 $\mathrm{nm}$ in diameter associated with the cored vesicles in the normal rats. On the basis of the present immunohistochemistry, we cannot discuss the electron mic roscopical property of stellate thyrotrophs and corticotrophs diffusively immunostained. Whether the 4 th and the 5 th folliculostellate cells with an abundance of secretory granules observed by Nagata et al. are immunohisto chemically identified as corticotrophs or as thyrotrophs will be reported in our next paper. We have reported here only the fact that the stellate cells with an embracement 
Table 1. Absorption test of antisera by porcine ACTH

\begin{tabular}{lccccc}
\hline \hline \multicolumn{1}{c}{ Antisera } & & \multicolumn{4}{c}{ Dose of $\mathrm{pACTH}$ (antigen) } \\
& Control & $1 \mu \mathrm{g} / \mathrm{m} l$ & $10 \mu \mathrm{g} / \mathrm{m} l$ & $100 \mu \mathrm{g} / \mathrm{m} l$ & $1 \mathrm{mg} / \mathrm{m} l$ \\
\hline o FSH & ++ & ++ & ++ & ++ & + \\
pACTH $^{1-39}$ & ++ & - & - & - & - \\
pACTH $^{17-39}$ & ++ & \pm & - & - & - \\
\hline
\end{tabular}

Expressed by the diversity in staining intensity of the same pituitary stellate cells on the adjacent sections between the control and tested materials.

of the acidophils are in general diffusively stained either with TSH $-\beta$ antiserum or with $\mathrm{pACTH}^{17-39}$ antiserum.

In this study, antisera against ovine FSH could stain not only the so-called gonadotrophs but also the stellate cells. It was really found on the adjacent sections that the same stellate cells were stained concomitantly with ovine FSH antiserum and with the pACTH ${ }^{17-39}$ antiserum. This coincidence of the cells in the immunostaining by two different antisera is assumed to be either because of the co-existence of two hormones in the single cells, or because of some contamination of the ovine FSH antiserum with the substance that can be bound to ACTH molecules. To solve the question, the absorption tests of the ovine FSH and $\mathrm{pACTH}^{17-39}$ antisera by porcine $\mathrm{ACTH}$ are needed to be carried out. As a result of the tests, the immunostainabilities of the $\mathrm{ACTH}$ antisera for the stellate cells disappeared at the dose of $10 \mu \mathrm{g} / \mathrm{ml}$, but those of the ovine FSH antiserum were not completely absorbed by the doses of less than $1 \mathrm{mg} / \mathrm{m} l$. On the other hand, the stainability of the ovine FSH antiserum for the typical gonadotrophs was never reduced despite the absorption by any dose of porcine ACTH (Table 1).

If ovine FSH antisera are tentatively contaminated with a great amount of ACTH antibody, it is likely that even $1 \mathrm{mg}$ of porcine ACTH does not absorb the contaminated ACTH antibody. In our opinion, the excessive contamination with pACTH antibody to the ovine FSH antisera seems inconsiderable, because ACTH molecules may not be almost contained in the purified ovine FSH used as the antigen.

From the results of absorption test of ovine FSH antisera, a possibility may arise that the single stellate cells simultaneously produce the FSH and ACTH, being compatible with the view of Moriarty and Garner (1977), who pointed out that some stellate cells contained the different two secretory granules separately immunostained with rat FSH- $\beta$ and pACTH $^{17-39}$ antisera. Antiserum against rat FSH- $\beta$ used by Moriarty and Garner seems more specific that rat FSH (whole) antiserum used in the present study. Nevertheless, the latter did not stain the stellate cells. In this respect, this observation is inconsistent with the findings of Moriarty and Garner. This inconsistency may come from the difference of precursors of ACTH molecules (Yallow and Berson, 1971; Orth et al., 1973; Eipper et al., 1976; Robert and Herbert, 1977; Yamada et al., 1978 and so on). The final conclusion as to the production of FSH and ACTH in the single stellate cells has not been drawn in the present study because of deficient evidences.

\section{Acknowledgements}

The authors would express their cordial thanks to Dr. A. F. Parlow (NIH, U.S.A.) for kindly supplying rat TSH- $\beta$ and rat FSH (whole) antisera, to Dr. M. Shiino (San Antonio, U.S.A.) for kındly supplying ovine FSH (whole) antiserum, and to Dr. S. Daikoku (Tokushima, Japan) for his kind valuable advices and encouragement during performance of our immunohistochemical study and for supplying porcine $\mathrm{ACTH}^{1-39}$ and porcine $\mathrm{ACTH}^{17-39}$ antiseva. 


\section{References}

Baker, B. L., S. Pek, A. R. Midgley, Jr. and B. E Gersten (1970). Anat. Rec. 166, 557.

Baker, B. L. and T. Drummon (1972). Am. J. Anat. 134, 395.

Eipper, B. A., R. E. Mains and D. Guenzi (1976). J. Biol. Chem. 251, 4121.

Moriarty, G. C. and N. S. Halmi (1972). Z. Zellforsch. 132, 1 .

Moriarty, G. C. and L. L. Garner (1977). Nature 265, 356.

Moriarty, G. C. and R. B. Tobin (1976). J. Histochem. Cytochem. 24, 1131.

Nagata, M., A. Mizunaga, S. Ema and F. Yoshimura
(1980). Endocrinol. Japon. 27, 13.

Orth, D. N., W. E. Nicholson, W. M. Mitchell, D. Ishland, M. Shapiro and R. L. Byyny (1973). Endocrinology 92, 385.

Siperstein, E. R. and K. J. Miller (1970). ibid. 86, 451.

Sternberger, L. A., P. H. Hardy, J. J. Cuculis and H. G. Meyer (1970). J. Histochem. Cytochem. 18, 315.

Robert, J. and E. Herbert (1977). Proc. Natl. Acad. Sci. USA, 74, 4826.

Yallow, R. S. and S. A. Berson (1971). Biochem. Biophys. Res. Commun. 44, 439.

Yamada, Y., S. Itoh, M. Miyashita, K. Kaneko, T. Watanabe, A. Shibata, H. Sasaki, K. Thuthui and R. Kayamori (1978). Acta Endocrinol. 89, 221. 